\title{
Study on Cementitious Properties and Hydration Characteristics of Steel Slag
}

\author{
Shuang Wang ${ }^{1}$, Changlong Wang ${ }^{2-4^{*}}$, Qunhui Wang ${ }^{1 *}$, Zhenyu Liu ${ }^{3}$, \\ Wei Qian', ChangZhi Jin ${ }^{3}$, Lie $\mathrm{Chen}^{3}, \mathrm{Li} \mathrm{Li}^{3}$ \\ ${ }^{1}$ School of Energy and Environmental Engineering, University of Science and Technology Beijing, \\ Beijing 100083, China \\ ${ }^{2}$ Jiangxi Key Laboratory of Mining Engineering, Jiangxi University of Science and Technology, \\ Ganzhou Jiangxi Province 341000, China \\ ${ }^{3}$ School of Civil Engineering, Hebei University of Engineering, Handan Hebei Province 056038, China \\ ${ }^{4}$ Tianjin Sunenergy Sega Environmental Science and Technology Co. Ltd, Tianjin 300000, China
}

Received: 25 April 2017

Accepted: 26 May 2017

\begin{abstract}
In order to improve the utilization of the steelmaking byproduct steel slag in the concrete industry, this paper mainly studied the cementitious and hydration properties of converter steel slag. X-ray diffraction (XRD), non-evaporable water amount, strength, and particle size distribution were measured and analyzed. The paste with steel slag and water can be slowly hardened, which indicates the weak cementitious capacity of steel slag. The hydration of steel slag is similar to that of cement. The hydration rate of steel slag is much slower than that of cement at the early age, while its rate is higher than cement at the curing age of 90 days. The hydration rate of steel slag increases as its specific surface area (SSA) increases, and the degree of hydration becomes similar in steel slag with varying SSA at the curing age of 180 days. The early-age hydration of cement can be inhibited to some extent when steel slag is added. And the inhibition effect increases as the replacement level of steel slag increases. There is a slow strength development of steel slag blend concrete with a low water-to-binder ratio at the early age, while this influence decreases as age increases. The mineral phases of steel-slag-blend hardened paste mainly includes hydration products $\left(\mathrm{Ca}(\mathrm{OH})_{2}\right.$ and $\left.\mathrm{C}-\mathrm{S}-\mathrm{H}\right)$, inert components $\left(\mathrm{C}_{2} \mathrm{~F}\right.$, magnetite, and $\mathrm{RO}$ phase $)$, and unhydrated phases $\left(\mathrm{C}_{3} \mathrm{~S}, \mathrm{C}_{2} \mathrm{~S}\right.$, gehlenite, and $\mathrm{C}_{12} \mathrm{~A}_{7}$ ).
\end{abstract}

Keywords: steel slag, cementitious properties, hydration characteristics, concrete

\section{Introduction}

Mineral admixtures have been widely used in concrete, and they have become an essential part in

*e-mail: 13716996653@139.com,wangqh59@163.com modern concrete technology. The utilization of mineral admixtures can dramatically decrease the emission of $\mathrm{CO}_{2}$ in the concrete industry [1-3]. As mineral admixtures, fly ash (FA) and ground blast furnace slag have been widely used in concrete [4]. Although the addition of FA and slag decreases the early-age strength of concrete, some other properties of concrete can be improved, such as 
increasing workability and performance, decreasing the inner temperature, and lowering the cracking potential [58]. The combined use of FA and slag can further improve the properties of concrete, thus the ternary concrete with FA and slag is widely used [9-11]. As the wide application of FA and slag, they have turned to scarce resources in some areas, which increases their price.

Steel slag is a kind of massive byproduct when lime is added to extract impurities during steelmaking, and its amount is about $15-20 \%$ of crude steel production [12]. The annual amount of steel slag is about 80 million tons in China, and the accumulated amount is about 500 million tons. And the utilization rate is $22 \%$, which is far below the target rate of $75 \%$ in the utilization of massive solid byproducts during China's $12^{\text {th }}$ Five-Year Plan. According to the different processes of steelmaking, steel slag can be categorized as converter slag, refining furnace slag, casting slag, electric furnace slag, pretreatment slag, etc. Among them, converter slag makes up more than $70 \%$ of the total in China. The utilization of steel slag mainly includes the applications in producing metallurgical raw materials, road works, innovative building materials, glass-ceramics, and environmental and agricultural fields. However, its application in the concrete industry is still minor. Wang et al. [13] and Zhang et al. [14] indicated that steel slag be used as mineral admixture in concrete and cement. The mineral compositions of steel slag include calcium aluminates $\left(\mathrm{C}_{3} \mathrm{~A}, \mathrm{C}_{12} \mathrm{~A}_{7}\right)$, calcium ferrites $\left(\mathrm{C}_{4} \mathrm{AF}\right.$, $\left.\mathrm{C}_{2} \mathrm{~F}\right)$, calcium silicates $\left(\mathrm{C}_{3} \mathrm{~S}, \mathrm{C}_{2} \mathrm{~S}\right)$, $\mathrm{RO}$ phase $(\mathrm{CaO}-\mathrm{MgO}-$ $\mathrm{MnO}-\mathrm{FeO}$ solid solution), free $\mathrm{MgO}$, free $\mathrm{CaO}, \mathrm{Fe}_{3} \mathrm{O}_{4}$, and so on [15-20]. Similar to cement, steel slag can react with water, producing $\mathrm{Ca}(\mathrm{OH})_{2}$, C-S-A-H gel, C-A-H crystal, $\mathrm{C}-\mathrm{S}-\mathrm{H}$ gel, etc. [20-22]. Thus steel slag is considered a supplemental cementitious material.

Due to the volume stability issue and its wide composition range, the application of steel slag into concrete is limited. It would be a huge economic and environmental benefit if hugely accumulated and widely distributed steel slag was used in concrete [23]. Thus, it is necessary to study the cementitious properties and hydration characteristics of steel slag. This paper will focus on the influence of fineness and replacement level

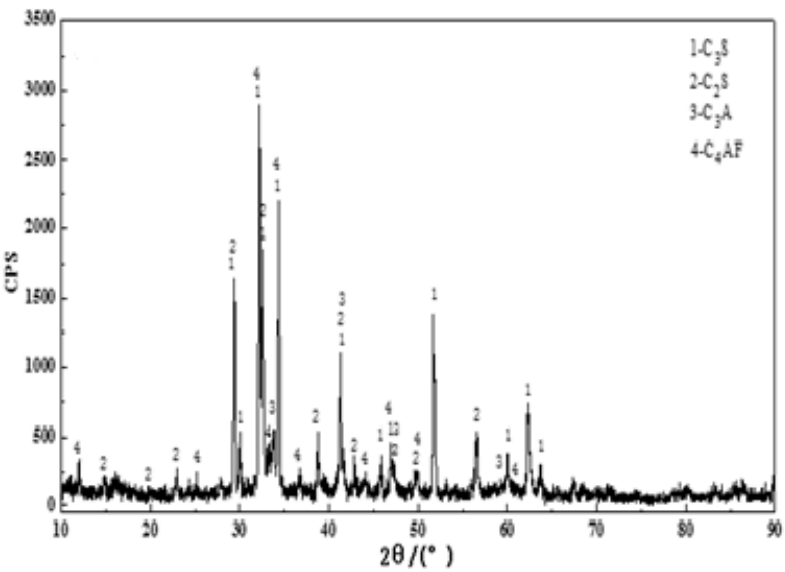

Fig. 1. Mineralogical phases of cement.

of steel slag on the cementitious and hydration properties by $\mathrm{XRD}$, strength test, non-evaporable water test, and particle side distribution analysis.

\section{Material and Methods}

\section{Materials}

Cement. The cement used was P.I 42.5 Portland cement, which complies with the Chinese National Standard GB 175-1999. The specific surface area of cement is $345 \mathrm{~m}^{2} \mathrm{~kg}^{-1}$. Its chemical composition and physical properties are shown in Tables 1 and 2, respectively. Fig. 1 shows its mineral components with $8.74 \% \mathrm{C}_{4} \mathrm{AF}$, $7.82 \% \mathrm{C}_{3} \mathrm{~A}, 29.81 \% \mathrm{C}_{2} \mathrm{~S}$, and $48.72 \% \mathrm{C}_{3} \mathrm{~S}$ by mass.

Steel slag. The steel slag used was basic oxygen furnace steel slag, which complies with the Chinese National Standard GB/T 20451-2006. The chemical compositions of steel are shown in Table 1. The mineral phases of steel slag are shown in Fig. 9. Table 1 shows that the amount of $\mathrm{CaO}$ in the steel slag was approximately $40.03 \%$, and the level of residual iron in the steel slag was approximately $14.81 \%$. According to the method of the basicity calculation proposed by Mason [24], the

Table 1. Chemical composition of cement and steel slag (wt. \%).

\begin{tabular}{|c|c|c|c|c|c|c|c|c|c|c|}
\hline Materials & $\mathrm{SiO}_{2}$ & $\mathrm{Al}_{2} \mathrm{O}_{3}$ & $\mathrm{Fe}_{2} \mathrm{O}_{3}$ & $\mathrm{FeO}$ & $\mathrm{MgO}$ & $\mathrm{CaO}$ & $\mathrm{Na}_{2} \mathrm{O}_{\text {eq }}$ & $\mathrm{MnO}$ & $\mathrm{P}_{2} \mathrm{O}_{5}$ & $\mathrm{LOI}$ \\
\hline Cement & 21.68 & 4.56 & 2.63 & - & 1.83 & 63.39 & 0.48 & - & 0.04 & 1.86 \\
\hline Steel slag & 17.41 & 5.74 & 12.62 & 7.68 & 9.95 & 40.03 & 0.27 & 0.68 & 2.78 & 1.65 \\
\hline
\end{tabular}

$\mathrm{Na}_{2} \mathrm{O}_{\text {equi }}=\mathrm{Na}_{2} \mathrm{O}+0.658 \mathrm{~K}_{2} \mathrm{O}$

Table 2. Physical properties of cement.

\begin{tabular}{|c|c|c|c|c|c|c|c|}
\hline \multirow{2}{*}{$\begin{array}{c}\text { Normal } \\
\text { consistency } \%\end{array}$} & \multicolumn{2}{|c|}{ Setting time/min } & \multirow{2}{*}{ Stability } & & \multicolumn{2}{c|}{ Flexural strength/MPa } & \multicolumn{2}{c|}{ Compressive strength/MPa } \\
\cline { 2 - 6 } \cline { 5 - 8 } & Initial setting & Final setting & & $3 \mathrm{~d}$ & $28 \mathrm{~d}$ & $3 \mathrm{~d}$ & $28 \mathrm{~d}$ \\
\hline 26.4 & 90 & 210 & qualified & 5.4 & 8.6 & 20.7 & 52.9 \\
\hline
\end{tabular}


Table 3. Particle size distribution of steel slag.

\begin{tabular}{|c|c|c|c|}
\hline Size/mm & $\begin{array}{c}\text { Individual } \\
\text { yield/\% }\end{array}$ & $\begin{array}{c}\text { Positive } \\
\text { cumulative } \\
\text { yield/\% }\end{array}$ & $\begin{array}{c}\text { Negative } \\
\text { cumulative } \\
\text { yield/\% }\end{array}$ \\
\hline+10 & 4.11 & 4.11 & 100.00 \\
\hline $10 \sim 4.75$ & 31.41 & 35.52 & 95.89 \\
\hline $4.75 \sim 2.36$ & 23.12 & 58.64 & 64.48 \\
\hline $2.36 \sim 1.18$ & 15.46 & 74.10 & 41.36 \\
\hline $1.18 \sim 0.6$ & 12.04 & 86.14 & 25.90 \\
\hline $0.6 \sim 0.3$ & 8.97 & 95.11 & 13.86 \\
\hline-0.3 & 4.89 & 100.00 & 4.89 \\
\hline Total & 100.00 & - & - \\
\hline
\end{tabular}

basicity of the steel slag used herein is 2.17. According to the particle size distribution of the steel slag listed in Table 3, the particles within the size range of 0.3-10 mm accounts for $82.03 \%$ of the total, which indicates that steel slag needs crushing before grinding.

Fine aggregate. ISO standard sand will be used as fine aggregate in mortar.

Coarse aggregate. Crushed limestone within the size $5-25 \mathrm{~mm}$ will be used as coarse aggregate in concrete.

\section{Methods}

\section{Specimen Preparation}

The steel slag used herein was crushed into particles of 1-2 $\mathrm{mm}$ in diameter using a fully sealed jaw crusher $(\mathrm{EP}-150 \times 125)$. Then the rushed steel slag was ground into the essential fineness by a ball mill $(\mathrm{SM} \Phi 500 \times 500)$.

The water-to-binder ratio is 0.30 and 0.45 for steel slag-water paste and cement-water paste, respectively. The fresh paste was cast into $40 \times 40 \times 160 \mathrm{~mm}$ molds and then cured in a moist room $\left(\mathrm{RH}>90 \%, 20 \pm 1^{\circ} \mathrm{C}\right)$ for one day. Then the demolded specimens were cured in lime water at $20 \pm 1^{\circ} \mathrm{C}$ until specific ages $(3,7,28,90$, and 180 days). The compressive and flexural strengths of specimens were measured at varying ages. The paste used for the measurement of non-evaporable water content was cast in sealed plastic centrifuge tubes, which prevents carbonation and water loss. The curing regime is the same as that of the aforementioned paste.

The mortar specimens with steel slag for compressive strength test were cast with the ground steel slag, and water and ISO standard sand with a ratio of 1:0.3:3. The curing regime is the same as the steel slag paste.

The steel slag blend concrete and plain concrete were cast into $100 \times 100 \times 100 \mathrm{~mm}$ molds. The density of concrete is considered as $2,400 \mathrm{~kg} \mathrm{~m}^{-3}$ and the replacement level of steel slag is $15 \%, 30 \%$, and $45 \%$ by mass (Table 4 ). The compressive strength was measured at the ages of $3,7,28$, 90 , and 180 days.

\section{Property Characterization}

According to the Chinese National Standard GB/T 19077.1-2008 Particle size analysis - Laser diffraction methods - Part 1: General principles, the particle size distribution of ground steel slag is analyzed using a laser particle size analyzer (MASTER SIZER 2000, the analysis range is $0.02 \sim 2,000.00 \mu \mathrm{m}$ ) with ethanol as the dispersant. The specific surface area is measured using a dynamic specific surface area analyzer (SSA-3200). The compressive strength test of mortars was based on the Chinese National Standard GB/T 17671-1999 Method of testing cement-determination of strength. The strength was measured using a hydraulic pressure testing machine (YES-300) with a maximum load of $300 \mathrm{KN}$ and a loading rate of $2.0 \pm 0.5 \mathrm{kN} / \mathrm{s}$. To prepare the samples for non-evaporable water content measurement, the crushed specimen (smaller than $80 \mu \mathrm{m}$ in diameter) was immersed in ethanol to stop hydration. The samples were dried at $65^{\circ} \mathrm{C}$ for $24 \mathrm{hrs}$ in an oven (DH-101), and then 1 2 g dried samples were burned at $1,050^{\circ} \mathrm{C}$ for $2 \mathrm{hrs}$ in a furnace (CD-1400X). And the mass loss in the furnace is used to calculate the nonevaporable water content. The XRD spectra were obtained using a D/Max-RC diffractometer (Japan) with $\mathrm{CuK} \alpha$ radiation, voltage of $40 \mathrm{kV}$, current of $150 \mathrm{~mA}, 2 \theta$ scanning ranging between $10^{\circ}$ and $90^{\circ}$, and the wavelength is $1.5406 \mathrm{~nm}$.

Table 4. Mix proportion of concrete.

\begin{tabular}{|c|c|c|c|c|c|c|}
\hline \multirow{2}{*}{$\mathrm{W} / \mathrm{B}$} & \multicolumn{5}{|c|}{ Raw material composition/( $\left.\mathrm{kg} \mathrm{m}^{-3}\right)$} & \multirow{2}{*}{ Dosage of steel slag/ $\%$} \\
\hline & Cement & Steel slag & Stone & Sand & Water & \\
\hline \multirow{4}{*}{0.48} & 400 & - & 759 & 1049 & 192 & - \\
\hline & 340 & 60 & 759 & 1049 & 192 & 15 \\
\hline & 280 & 120 & 759 & 1049 & 192 & 30 \\
\hline & 220 & 180 & 759 & 1049 & 192 & 45 \\
\hline \multirow{4}{*}{0.32} & 400 & - & 786 & 1086 & 128 & - \\
\hline & 340 & 60 & 786 & 1086 & 128 & 15 \\
\hline & 280 & 120 & 786 & 1086 & 128 & 30 \\
\hline & 220 & 180 & 786 & 1086 & 128 & 45 \\
\hline
\end{tabular}




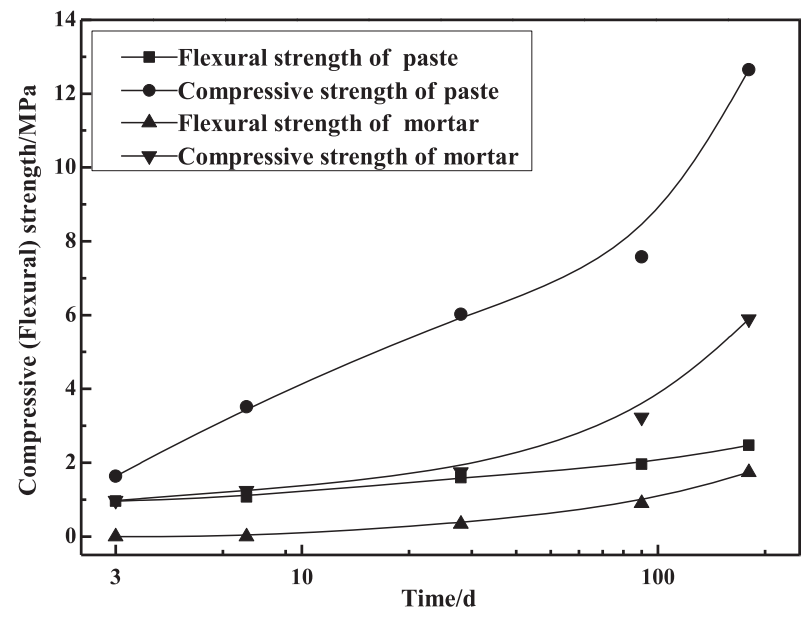

Fig. 2. Strength development of steel slag pastes and mortars.

\section{Results and Discussion}

\section{The Cementitious Properties of Steel Slag}

The steel slag with a SSA of $460 \mathrm{~m}^{2} \mathrm{~kg}^{-1}$ was used to study the cementitious properties of steel slag. The strength development of steel slag paste and mortar is shown in Fig. 2. The compressive and flexural strength of steel slag paste and mortar is low at the early ages, which is due to the small amount of formed C-S-H from steel slag. As the age increases, the amount of formed C-S-H increases, and the strength dramatically increases. And it should be noted that there is a big difference between the strength of paste and mortar at the same age. The maximum compressive strength of the steel slag paste is $12.65 \mathrm{MPa}$ at 180 days, while that of mortar is $5.89 \mathrm{MPa}$. This indicates the weak cementitious capability of steel slag and that steel slag achieves strength after long-term hydration.

The non-evaporable water content is a common indicator of the degree of hydration for cementitious materials. In the hardened cementitious materials, the water

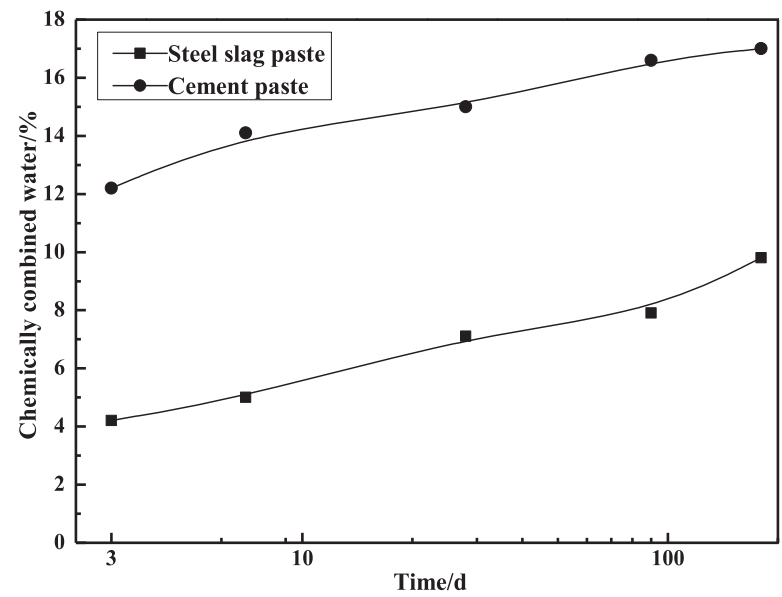

Fig. 3. Chemically combined water content of steel slag and cement paste. inside can be separated into two portions. One portion of water exists as free water in the pores of the materials, while the other portion is considered non-evaporable water as a component of hydration products in a form of $\mathrm{OH}^{-}$. The amount of non-evaporable water increases as the amount of hydration products increases. Fig. 3 shows the non-evaporable water amounts of steel slag paste and cement paste at varying ages. The non-evaporable water content of cement paste is much higher than that of steel slag paste at the early age, while its increase at the late ages is smaller than that of steel slag paste. During the curing age from 90 to 180 days, the non-evaporable water content increased by $0.42 \%$ and $1.91 \%$ in the cement paste and steel slag paste, respectively. The non-evaporable water content of the cement paste at the age of 180 days is $17.02 \%$. At the same age, the amount of steel slag only accounts for $57.64 \%$ that of the cement paste. There is a maximum difference of the non-evaporable water content with a value of $9.10 \%$ between the two pastes at the age of seven days. As the age increases, the difference becomes smaller, and there is a minimal difference with a value of $7.21 \%$ at the age of 180 days. This indicates that the hydration rate of the steel slag exceeds that of cement after seven days.

The strength development of the steel slag has a similar trend to that of the non-evaporable water content, which indicates the slow hydration of the steel slag and its higher contribution to long-term hydration.

\section{Influence of Steel Slag Fineness on Strength}

After 40 mins and 70 mins grinding in the ball mill, the SSA of steel slag is $460 \mathrm{~m}^{2} \mathrm{~kg}^{-1}$ and $610 \mathrm{~m}^{2} \mathrm{~kg}^{-1}$. And the particle size distributions of ground steel slag and cement are shown in Fig. 4. Theoretically, mechanical grinding has no influence on the mineral phases, chemical composition, and hydration products of the steel slag. Increasing the SSA of the steel slag has some influence on its cementitious properties in two aspects. One aspect is that the main ground mineral phases are $\mathrm{C}_{3} \mathrm{~S}$ and $\mathrm{C}_{2} \mathrm{~S}$ due to the inert RO phase being hard to grind. And another

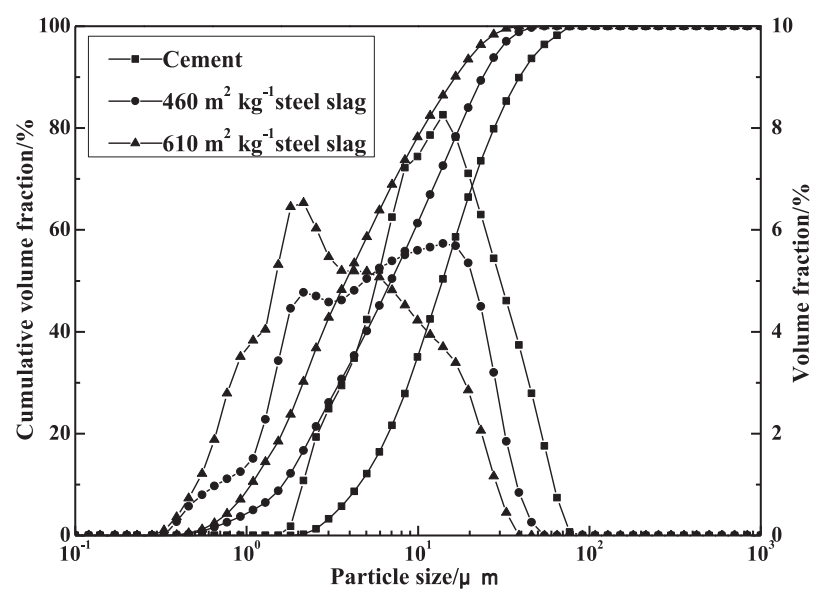

Fig. 4. Particle size distribution of steel slag and cement. 
aspect is that $\mathrm{C}_{3} \mathrm{~S}$ and $\mathrm{C}_{2} \mathrm{~S}$ can be ground to be finer since the steel slag is smaller than $1 \mu \mathrm{m}$ on account of more portion than that in coarse steel slag.

As shown in Fig. 4, as the grinding time increases, the particle size distribution of the steel slag becomes narrower and the peak particle size decreases from $14.09 \mu \mathrm{m}$ to $3.14 \mu \mathrm{m}$. More than $50 \%$ of the ground steel slag has a particle diameter smaller than $10 \mu \mathrm{m}$, and submicron particles appear, which consist of $1.64 \%$ and $3.65 \%$ of the total steel slag particles after 40 and
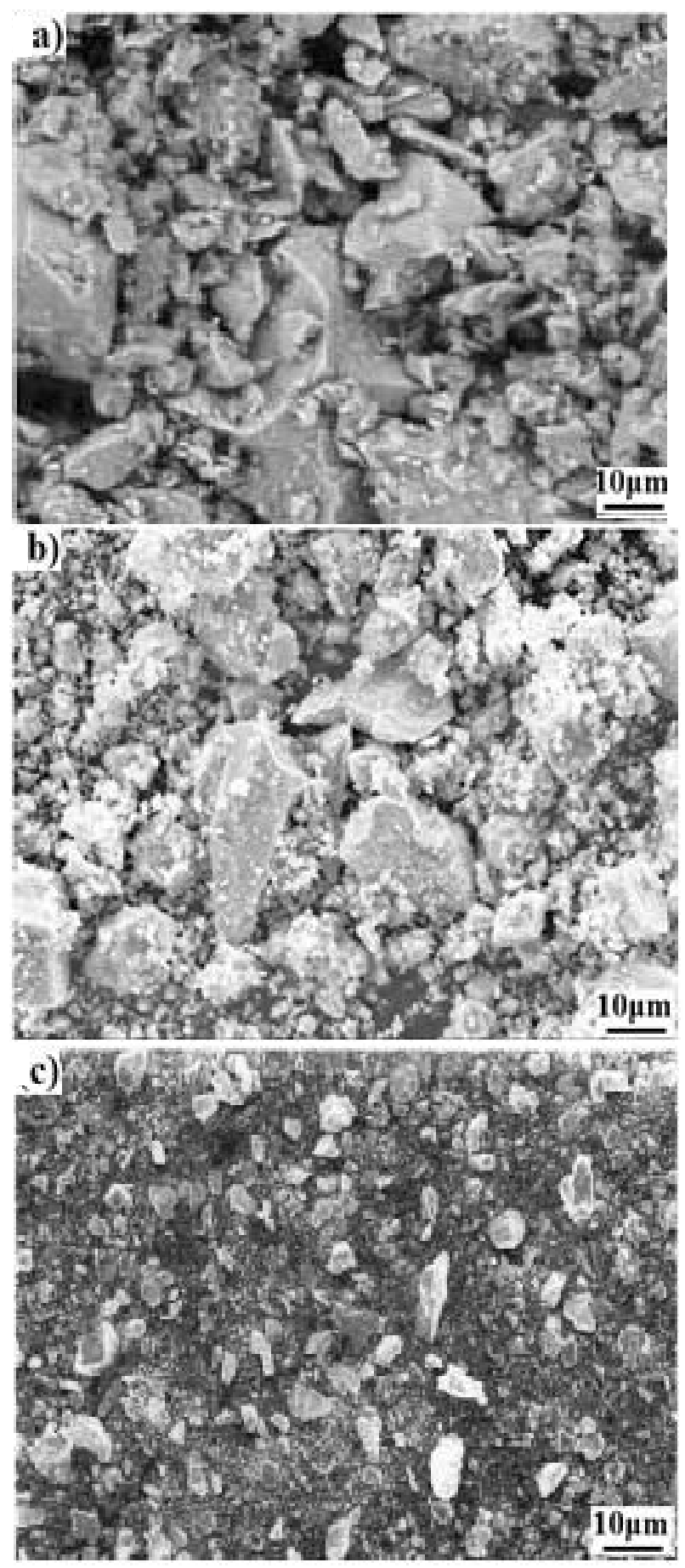

Fig. 5. FE--SEM images of cement and steel slag powder: a) cement, b) SSA of $460 \mathrm{~m}^{2} \mathrm{~kg}^{-1}$, and c) SSA of $610 \mathrm{~m}^{2} \mathrm{~kg}^{-1}$.
Table 5. Characteristic particle size of steel slag at different grinding times.

\begin{tabular}{|c|c|c|c|}
\hline \multirow{2}{*}{$\begin{array}{c}\text { Grinding } \\
\text { time } / \text { min }\end{array}$} & \multicolumn{3}{|c|}{ Characteristics particle size/ $\mu m$} \\
\cline { 2 - 4 } & $\mathrm{D}_{10}$ & $\mathrm{D}_{50}$ & $\mathrm{D}_{90}$ \\
\hline 40 & 1.58 & 6.64 & 22.47 \\
\hline 70 & 1.13 & 4.12 & 17.78 \\
\hline
\end{tabular}

70 mins, respectively. There is a larger portion of particles smaller than $10 \mu \mathrm{m}$ and submicron particles in ground steel slag than in cement (Fig. 5). As listed in Table 5, the characteristic particle sizes $\mathrm{D}_{10}, \mathrm{D}_{50}$, and $\mathrm{D}_{90}$ decrease as grinding time increases. As the grinding time increases from 40 to 70 mins, $D_{10}$ of the steels slag decreases from $1.58 \mu \mathrm{m}$ to $1.13 \mu \mathrm{m}, \mathrm{D}_{50}$ from $6.64 \mu \mathrm{m}$ to $4.12 \mu \mathrm{m}$, and $\mathrm{D}_{90}$ from $22.47 \mu \mathrm{m}$ to $17.78 \mu \mathrm{m}$. This indicates that the portion of small particles increases as the grinding time increases.

Fig. 6 shows the compressive strength of the paste and mortar made from the steel slag with two fineness values (after 40 and 70 mins grinding). As the curing age increases, the strength of both paste and mortar increases. There is little difference between the strength of both paste and mortar made from the steel slag with different fineness at the ages of 3 and 7 days. As the curing age increases to 28, 90, and 180 days, the strength of paste and mortar from the 70 mins grinding steel slag is higher than that from 40 mins grinding steel slag. At the age of 28 days, the compressive strength of the paste from 70 mins grinding steel slag is $27.91 \%$ higher than that from 40 mins grinding steel slag. At the ages of 90 and 180 days, the value is $29.29 \%$ and $12.25 \%$ for paste and $23.23 \%$ and $9.34 \%$ for mortar, respectively. Strength sees the largest difference at the age of 90 days, while the difference at the age of 180 days is smaller. Because the fineness of active components of $\mathrm{C}_{3} \mathrm{~S}$ and $\mathrm{C}_{2} \mathrm{~S}$ are larger in SSA of $610 \mathrm{~m}^{2} \mathrm{~kg}^{-1}$ steel slag, the early hydration reaction is faster and can produce more hydration products than SSA

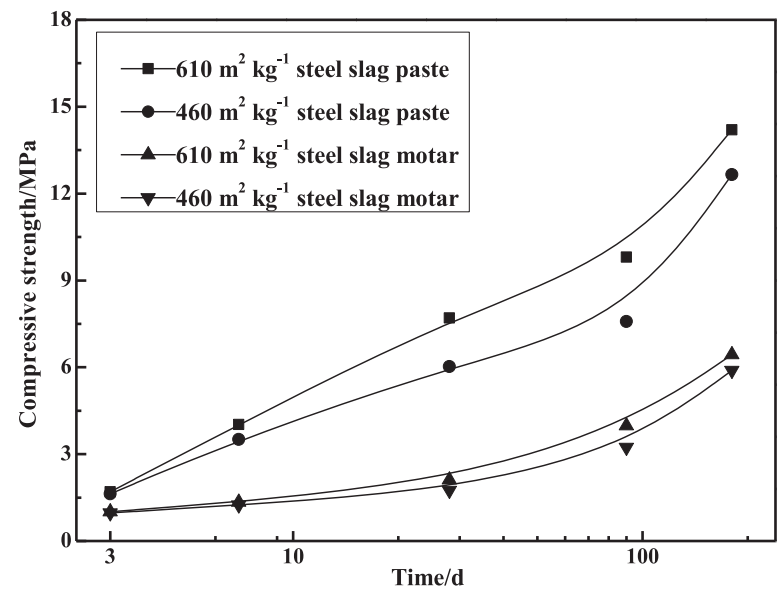

Fig. 6. Influence of steel slag fineness on the strength of paste and mortar. 


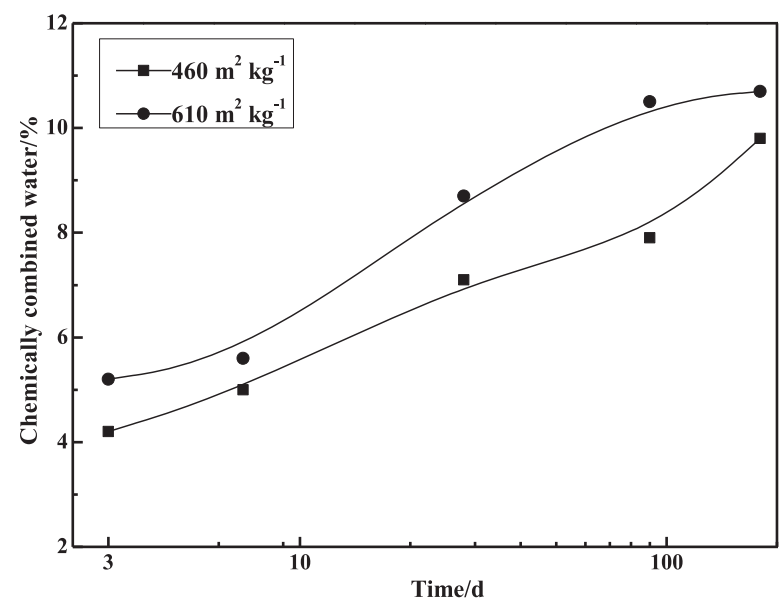

Fig. 7. Chemically combined water content of different fineness steel slag paste.

of $460 \mathrm{~m}^{2} \mathrm{~kg}^{-1}$ steel slag. As the curing age is extended, the number of active components in the steel slag is reduced, so the change rate of strength is decreased in the late age.

Fig. 7 shows the non-evaporable water content of the paste made from the steel slag with the different fineness. The non-evaporable water content in the paste with 70 min grinding steel slag is $1 \%$ higher than that with 40 mins grinding steel slag at the age of one day. As the curing age increases from 28 to 90 days, the difference increases from 1.6 to $2.6 \%$. This indicates that increasing the fineness of the steel slag can improve hydration at both early and late ages. It should be noted that the difference becomes $0.9 \%$ smaller by the age of 180 days. The content of $\mathrm{C}_{3} \mathrm{~S}$ and $\mathrm{C}_{2} \mathrm{~S}$ in both steel slag is the same, and the difference lies in the hydration rate due to the different fineness. At the age of 180 days, most $\mathrm{C}_{3} \mathrm{~S}$ and $\mathrm{C}_{2} \mathrm{~S}$ phases can be considered to be hydrated. Thus, at the age of 180 days there is a small difference in the non-evaporable water content of the paste with different steel slag as analyzed. The above analysis suggests that the degree of hydration of $\mathrm{C}_{3} \mathrm{~S}$ and $\mathrm{C}_{2} \mathrm{~S}$ increases after mechanical grinding. The trend in non-evaporable water content is similar to that of compressive strength.

\section{Influence of Steel Slag Replacement Level on Compressive Strength of Concrete}

Steel slag with SSA of $610 \mathrm{~m}^{2} \mathrm{~kg}^{-1}$ was used in the concrete with a water-to-binder ratio of 0.48 , and strength development is shown in Fig. 8. As the replacement level of steel slag increases, the strength of the concrete decreases at the same age. And at the early age the strength developed slowly. At the age of three days, the strength of the concrete with $45 \%$ steel slag is $1.2 \mathrm{MPa}$. By comparing the strength of the steel blend concrete and plain concrete, the relative strength of the steel slag blend concrete can be calculated. At the age of seven days, the strength decreases by $18.3 \%, 41.7 \%$, and $86 \%$ in the concrete with

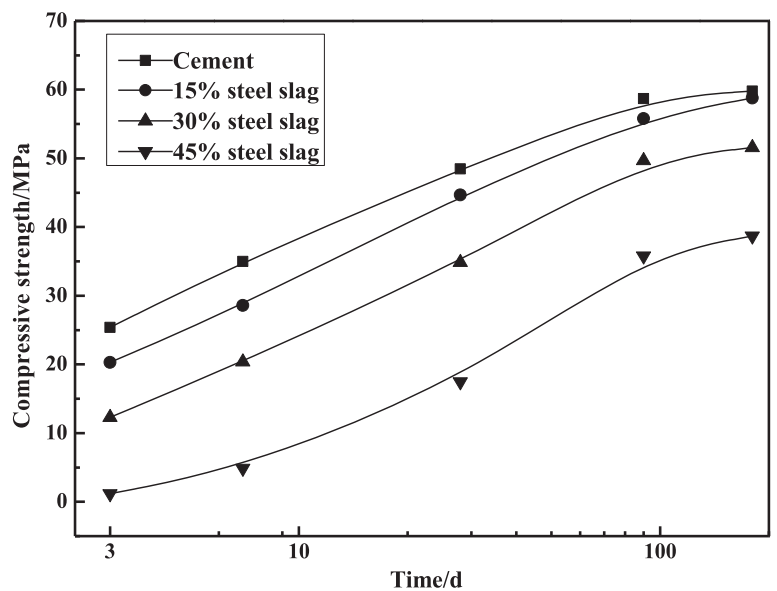

Fig. 8. Influence of content of steel slag on compressive strength $(\mathrm{W} / \mathrm{B}=0.48)$.

$15 \%, 30 \%$, and $45 \%$ steel slag, respectively. As of the concrete with $45 \%$ steel slag, the strength decreases by $95.3 \%, 86 \%$, and $63.9 \%$ at the ages of 3,7 , and 28 days. This indicates the low reactivity of steel slag at the early age. When some portion of steel slag is replaced by steel slag, the amount of cementitious materials responsible for the early age strength decreases. Moreover, the addition of steel slag decreases the degree of hydration of cement at the early age by inhibiting the hydration of cement. And the inhibition effect increases as the replacement level of steel slag increases.

As shown in Fig. 9, as the curing age of concrete with a water-to-binder ratio of 0.32 increases, the strength difference between steel slag blend concrete and plain concrete decreases. And this trend becomes more obvious in the concrete with a higher replacement level of steel slag. At the age of 180 days, the strength of concrete with $15 \%, 30 \%$, and $45 \%$ steel slag is $94.8 \%, 88.9 \%$, and $83.6 \%$ of that of plain concrete, respectively. This indicates that the larger replacement level of steel slag has

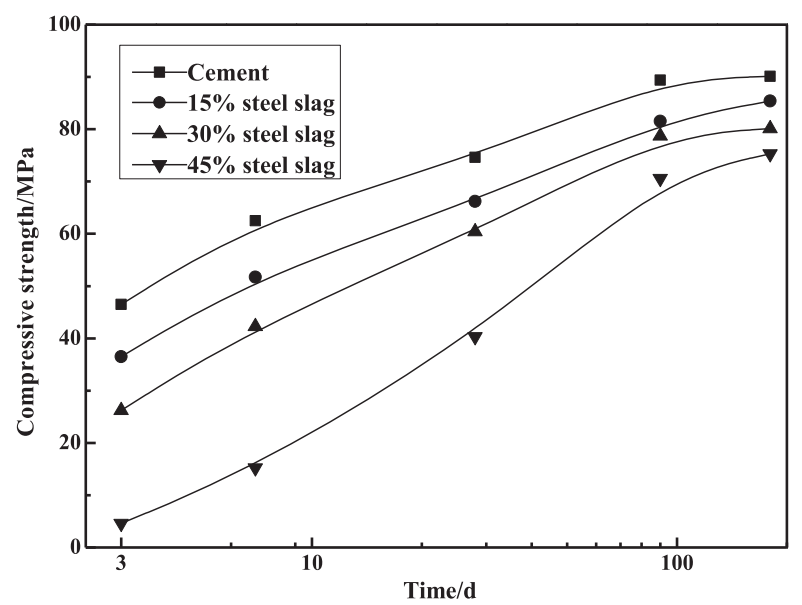

Fig. 9. Influence of content of steel slag on compressive strength $(\mathrm{W} / \mathrm{B}=0.32)$ 


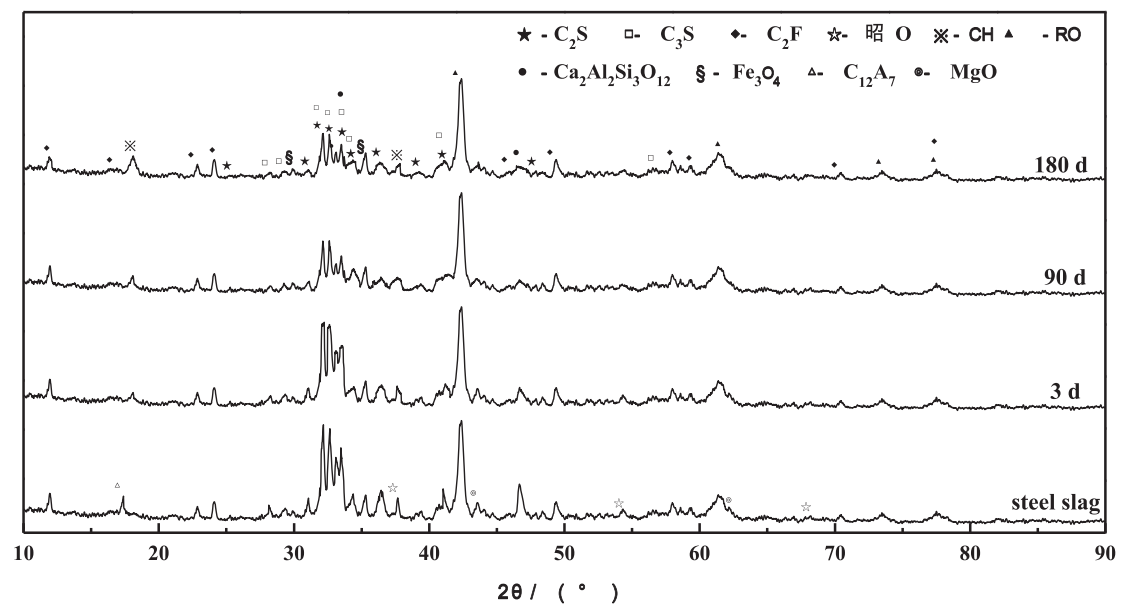

Fig. 10. XRD spectra of steel slag and steel slag hydrated at various ages.

a positive effect on the long-term hydration of cement. By comparing the strength of concrete in Figs 8 and 9, it can be implied that the degree of reaction of steel slag and its contribution to the strength of concrete increases as the curing age increases. As some portion of cement is replaced by steel slag, the actual water-to-cement ratio increases due to the larger water demand of cement than steel slag. Thus, cement has more water to hydrate in a higher water-to-cement ratio. However, the limited positive effect of steel slag on cement hydration results in its more obvious improvement for long-term hydration at a lower cement-to-binder ratio.

\section{The Hydration Products of Steel Slag}

Fig. 10 shows the XRD spectra of steel slag and hardened steel slag paste at the ages of 3, 90, and 180 days. The mineral phases of steel slag include $\mathrm{C}_{2} \mathrm{~S}, \mathrm{C}_{3} \mathrm{~S}, \mathrm{C}_{2} \mathrm{~F}$, $\mathrm{C}_{12} \mathrm{~A}_{7}$, RO phase (CaO-MgO-MnO-FeO solid solution), $\mathrm{Ca}_{2} \mathrm{Al}_{2} \mathrm{Si}_{3} \mathrm{O}_{12}, \mathrm{Fe}_{3} \mathrm{O}_{4}$, free $\mathrm{Cao}$, and free $\mathrm{MgO}$, among which $\mathrm{C}_{2} \mathrm{~S}, \mathrm{C}_{3} \mathrm{~S}$, and RO phase are the main phases. A small amount of $\mathrm{C}_{4} \mathrm{AF}$ can be obtained in steel slag due to the replacement of $\mathrm{Al}$ in $\mathrm{C}_{2} \mathrm{~F}$. Considering that $\mathrm{Al}$ atoms are mainly in the phases of $\mathrm{C}_{12} \mathrm{~A}_{7}$ and $\mathrm{Ca}_{2} \mathrm{Al}_{2} \mathrm{Si}_{3} \mathrm{O}_{12}$, the amount of $\mathrm{C}_{4} \mathrm{AF}$ is small. As the curing age of steel slag paste increases, the peak intensity of $\mathrm{C}_{2} \mathrm{~S}, \mathrm{C}_{3} \mathrm{~S}, \mathrm{C}_{2} \mathrm{~F}$, and $\mathrm{C}_{12} \mathrm{~A}_{7}$ decreases, which indicates their hydration. The intensity decreases more in the long term, and this is in accordance with the larger strength increases at the late ages in Fig. 9. The peak intensity of $\mathrm{C}_{2} \mathrm{~F}, \mathrm{Fe}_{3} \mathrm{O}_{4}$, and RO phase stay constant, which indicates they do not participate in the hydration. The main hydration products are $\mathrm{C}-\mathrm{S}-\mathrm{H}$ and $\mathrm{Ca}(\mathrm{OH})_{2}$. No peak can be found for C-S-H in the spectra since C-S-H is poorly crystallized. The peak of $\mathrm{Ca}(\mathrm{OH})_{2}$ can hardly be identified at the age of three days due to the low degree reaction of steel slag.

In summary, the mineral phases in hardened streel slag paste include hydration products $\left(\mathrm{Ca}(\mathrm{OH})_{2}\right.$ and $\left.\mathrm{C}-\mathrm{S}-\mathrm{H}\right)$, inert components $\left(\mathrm{C}_{2} \mathrm{~F}, \mathrm{Fe}_{3} \mathrm{O}_{4}\right.$, and $\mathrm{RO}$ phase $)$, and unhydrated phases $\left(\mathrm{C}_{3} \mathrm{~S}, \mathrm{C}_{2} \mathrm{~S}, \mathrm{Ca}_{2} \mathrm{Al}_{2} \mathrm{Si}_{3} \mathrm{O}_{12}\right.$, and $\left.\mathrm{C}_{12} \mathrm{~A}_{7}\right)$. As the curing age increases, the amount of $\mathrm{Ca}(\mathrm{OH})_{2}$ and
C-S-H increases, the amount of inert phases stay constant, and the amount of unhydrated components decreases.

\section{Conclusions}

1. Steel slag has weak cementitious capability, and the slowly hardened paste and mortar made from steel slag can obtain low strength. It early-age degree of hydration is far lower than that of cement. And it can contribute more to strength due to its larger hydration rate than that of cement at a late age.

2. By analyzing the influence of steel slag fineness on its cementitious properties, increasing the fineness can help increase the hydration rate at the early age as well as the late age. After 90 days of curing, the hydration rate decreases and the degree of hydration is similar for steel slag with different fineness at the age of 180 days.

3. The early-age hydration of cement can be inhibited to some extent when steel slag is added. And the inhibition effect increases as the replacement level of steel slag increases. There is a slow strength development of steel slag-blend concrete with a low water-to-binder ratio at the early age. As age increases, the strength increases more in steel-slag-blend concrete, while the negative influence of steel slag on concrete strength decreases.

4. The mineral phases of steel-slag-blend hardened paste mainly includes hydration products $\left(\mathrm{Ca}(\mathrm{OH})_{2}\right.$ and $\mathrm{C}-\mathrm{S}-\mathrm{H})$, inert components $\left(\mathrm{C}_{2} \mathrm{~F}, \mathrm{Fe}_{3} \mathrm{O}_{4}\right.$, and $\mathrm{RO}$ phase), and unhydrated phases $\left(\mathrm{C}_{3} \mathrm{~S}, \mathrm{C}_{2} \mathrm{~S}, \mathrm{Ca}_{2} \mathrm{Al}_{2} \mathrm{Si}_{3} \mathrm{O}_{12}\right.$, and $\mathrm{C}_{12} \mathrm{~A}_{7}$ ).

\section{Acknowledgements}

The authors gratefully acknowledge financial support from the China Postdoctoral Science Foundation (2016M602082), the Natural Science Foundation of Hebei Province (E2015402057), the Science and 
Technology Research Project of Higher Education Universities in Hebei Province (ZD2016014), the Comprehensive Utilization of Tailing Resources Key Laboratory of Shaanxi Province (2014SKY-WK001), the Construction Science and Technology Foundation of Hebei Province (2012-136), the Handan Science and Technology Research and Development Plan Program (1621211040-3), and the Jiangxi Postdoctoral Daily Fund Project (2016RC30).

\section{References}

1. NEMATOLLAHI B., SANJAYAN J. Effect of different superplasticizers and activator combinations on workability and strength of fly ash based geopolymer. Materials and Design, 57 (5), 667, 2014.

2. WANG Q., YAN P.Y., YANG J.W. Comparison of hydration properties between cement-GGBS-fly ash blended binder and cement-GGBS-steel slag blended binder. Journal of Wuhan University of Technology-Materials Science Edition, 29 (2), 273, 2014.

3. WU Z.M, KHAYAT K.H., SHI C.J. Effect of nano-SiO particles and curing time on development of fiber-matrix bond properties and microstructure of ultra-high strength concrete. Cement and Concrete Research, 95, 247, 2017.

4. ZHAO H., SUN W., WU X.M., GAO B. The properties of the self-compacting concrete with fly ash and ground granulated blast furnace slag mineral admixtures. Journal of Cleaner Production, 95, 66, 2015.

5. ANASTASIOU E., FILIKSA K.G., STEFANIDOU M. Utilization of fine recycled aggregates in concrete with fly ash and steel slag. Construction and Building Materials, 50 (5), 154, 2014

6. UPADHYAYA S., GOULIAS D., OBLA K. Maturity-based field strength predictions of sustainable concrete using highvolume fly ash as supplementary cementitious material. Journal of Materials in Civil Engineering, 27 (5), 69, 2015.

7. AÏTCIN P.C. WILSON W. Cementy dzisiaj-betony jutra. Cement Wapno Beton, 81 (19), 349, 2014

8. ANASTASIOU E., SHEHATA M.H. Utilization of fine recycled aggregates in concrete with fly ash and steel slag. Construction and Building Materials, 53 (3), 267, 2014.

9. ARULRAJAH A., MOHAMMADINIA A., PHUMIPHAN I., HORPIBULSUK S., SAMINGTHONG W. Stabilization of recycled demolition aggregates by geopolymers comprising calcium carbide residue, fly ash and slag precursors. Construction and Building Materials, 114, 864, 2016.

10. KUDER K., LEHMAN D., BERMAN J., HANNESSON G., SHOGREN R. Mechanical properties of self-consolidating concrete blended with High volumes of fly Ash and slag. Construction and Building Materials, 34 (34), 285, 2012.
11. WANG J.L., NIU K.M., YANG Z.F., ZHOU M.K., SUN L.Q., KE G.J. Effects of fly ash and ground granulated blastfurnaces slag on properties of high-strength concrete. Key Engineering Materials, 405-406, 219, 2009.

12. ZHANG T.S., YU Q.J., WEI J.X. Investigation on mechanical properties, durability and micro-structural development of steel slag blended cements. Journal of Thermal Analysis and Calorimetry, 110 (2), 1, 2012.

13. WANG Q., YAN P.Y. Hydration properties of basic oxygen furnace steel slag. Construction and Building Materials, 24 (7), 1134, 2010

14. ZHANG T.S., YU Q.J., WEI J.X., LI J.X.MI G.D., WANG Q. Investigation on mechanical properties, durability and micro-structural development of steel slag blended cements. Journal of Thermal Analysis and Calorimetry, 110 (1), 633, 2012.

15. SHI C.J. Characteristics and cementitious properties of ladle slag fines from steel production. Cement and Concrete Research, 32 (3), 459, 2002.

16. KOUROUNIS S., TSIVILIS S., TSAKIRIDIS P.E. Properties and hydration of blended cements with steelmaking slag. Cement and Concrete Research, 37 (6), 815, 2007.

17. WALIGORA J., BULTEEL D., DEGRUGILLIERS P., DAMIDOT D., POTDEVIN J.L. Chemical and mineralogical characterizations of LD converter steel slags: A multianalytical techniques approach. Materials Characterization, 61(1), 39, 2010.

18. LIU S.J., HU Q.Q., ZHAO F.Q., CHU X.M. Utilization of steel slag, iron tailings and fly ash as aggregates to prepare a polymer-modified waterproof mortar with a core-shell styrene-acrylic copolymer as the modifier. Construction and Building Materials, 72, 15, 2014.

19. YAN P.Y., MI G.D., WANG Q. A comparison of early hydration properties of cement-steel slag binder and cementlimestone powder binder. Journal of Thermal Analysis and Calorimetry, 115 (1), 193, 2014

20. WANG Q., YANG J.W., YAN P.Y. Influence of initial alkalinity on the hydration of steel slag. Science China Technological Sciences, 55 (12), 3378, 2012.

21. WANG Q., YAN P.Y., FENG J.W. A discussion on improving hydration activity of steel slag by altering its mineral compositions. Journal of Hazardous Materials, 186 (2-3), 1070, 2011.

22. LI Z.B., ZHAO S.Y., ZHAO X.G., HE T.S. Leaching characteristics of steel slag components and their application in cementitious property prediction. Journal of Hazardous Materials, 199-200 (1), 448, 2012.

23. ZHANG T.S., YU Q.J., WEI J.X., LI J.X., ZHANG P.P. Preparation of high performance blended cements and reclamation of iron concentrate from basic oxygen furnace steel slag. Resources, Conservation and Recycling, 56 (1), 48, 2011.

24. MASON B. The constitution of some open-heart slag. Journal of Iron and Steel Institute, 11, 69, 1994. 